\title{
Change of cerebral metabolites and activated region by lumbar mechanical stimulus in the patient with chronic low back pain
}

\author{
Takuya Kameda ${ }^{1}$, Miho Sekiguchi', Sei Fukui ${ }^{2}$, \\ Shoji Yabuki ${ }^{1}$, and Shin-ichi Konno ${ }^{1}$ \\ ${ }^{1}$ Department of Orthopaedic Surgery, School of Medicine Fukushima Medical University \\ 2Department of Anesthesiology, Interdisciplinary Pain Management Center, \\ Shiga University of Medical Science Hospital
}

\begin{abstract}
Studies of brain imaging in chronic low back pain (CLBP) patients have been recently increased. First, MR spectroscopy (MRS) was performed in CLBP patients $(n=60)$ and control subjects $(n=56)$ to evaluate the effects of CLBP on metabolites in the anterior cingulate cortex (ACC). Negative effects of CLBP on the N-acetyl aspartate (NAA) levels and positive effects on the glutamate + glutamine/creatine $(\mathrm{Glx} / \mathrm{Cr})$ ratios in the ACC were found. The result suggests the hypothesis that excessive Glx leads to neuronal dysfunction and/or death, which was reflected as a low NAA level in the ACC of CLBP patients. Second, The NAA/Cr and NAA/choline ratios in the thalamus were compared between 6 patients with the left side of unilateral pain and 6 control patients. In the right thalamus, the NAA/Cr in the patients with pain was significantly lower compared with the control patients, and there were significant correlations between the numerical rating scale (NRS) and NAA levels. Lumbar pain can be assessed indirectly by analyzing the decrease in NAA concentration in the thalamus. Third, to explore a pathologic pattern of cerebral activation in chronic LBP patients, 8 healthy volunteers and 6 patients with idiopathic, chronic LBP were recruited and performed functional MRI (fMRI). Each subject was placed in the prone position on a 3 Tesla MRI scanner, and performed lumbar mechanical stimulus. The pressure was established at either 3 or 5 on the $10-\mathrm{cm}$ visual analog scale (VAS) using 25 - $\mathrm{ml}$ syringe. Pain thresholds were smaller than in healthy subjects. LBP patients showed augmented activation compared with healthy volunteers specifically at the right insula, supplementary motor, and PCC. Chronic LBP patients showed increased tenderness at the lower back and augmented cerebral activation. The LBP-related activation is characterized by the absence of sensory-discriminative component. Fourth, 21 patients with cLBP were recruited and divided into two groups on the basis of scores on the patient
\end{abstract}


version of the Brief Scale for Psychiatric problems in Orthopaedic Patients (BS-POP) scores: $\geqq 17$ (high-score group) and $<17$ (non-high-score group). Subjects in the high-score group had more intense daily pain and lower quality of life than those in the non-high-score group. Activation at the nucleus accumbens (NAc) was smaller in the high-score group than in the non-high-score group. The presence of psychiatric problems was associated with attenuated activity of the NAc in cLBP patients.

Keywords

Chronic low back pain; fMRI; MRS

Received: 31 October 2016

Accepted: 28 November 2016

慢性腰痛患者における脳代謝物質と疼痛刺激による脳賦活部位の変化

亀田 拓哉 $1 /$ 関口 美穂 $1 /$ 福井 聖 $2 /$ 矢吹 省司 $1 /$ 紺野 慎一 1

福島県立医科大学 整形外科学講座

${ }^{2}$ 滋賀医科大学 麻醉学講座 ペインクリニック科

\section{はじめに}

腰痛は，70～85\%の人が一生に一度は経験す る痛みであり，その有病率は15４5\%である 1 。 しかし，慢性腰痛と画像上の腰椎の異常所見は 相関しないことが多く11,13), 局所の変化のみで 慢性腰痛のメカニズムを説明することはできな い。近年, 慢性腰痛患者における形態学的, 機 能的な脳イメージング研究が行われ, 中枢神経 系での変化を捉える試みがなされている。本稿 では，当講座で検討した慢性腰痛患者における 脳代謝物質や疼痛誘発時の脳賦活部位の変化に ついての研究成果を中心に概説する。

\section{慢性腰痛患者の前帯状回における 脳代謝物質の変化}

プロトン磁気共鳴スペクトロスコピー （MRS）では，MR装置を用い，ある特定の代 謝物質濃度を非侵襲的に測定することができる。 MRSは測定部位として設定した脳領域に，RF パルスを繰り返しかけ, 含まれる水素原子が共 鳴し緩和することで発生する電磁場を測定し, 得られる核磁気共鳴スペクトルを解析する手法 である。筆者らは, 慢性腰痛患者 60 名と, 健 常者 56 名に対し， 3 テスラ MR装置を用いて MRSを行った。関心領域を前帯状回 (anterior cingulate cortex: ACC) に設定し，ACCでの脳 代謝物質の変化を測定した。ACCは大脳辺縁 
Table 1 Impact of CLBP to metabolites in the ACC

\begin{tabular}{|c|c|c|c|c|c|c|}
\hline & \multicolumn{2}{|c|}{$\begin{array}{c}\text { CLBP } \\
(\mathrm{CLBP}=1, \text { Controls }=0)\end{array}$} & \multicolumn{2}{|c|}{ Age (y) } & \multicolumn{2}{|c|}{$($ Male $=1$, Female $=0)$} \\
\hline & B & $p$ & B & $p$ & B & $p$ \\
\hline \multicolumn{7}{|c|}{ Absolute concentration } \\
\hline NAA & -0.675 & $<0.001 *$ & -0.010 & $0.036^{*}$ & -0.354 & $0.013^{*}$ \\
\hline Glu & -0.167 & 0.451 & -0.012 & 0.054 & -0.310 & 0.104 \\
\hline Glx & 0.265 & 0.472 & -0.010 & 0.365 & -0.039 & 0.903 \\
\hline Ins & -0.269 & 0.089 & 0.004 & 0.372 & -0.259 & 0.057 \\
\hline \multicolumn{7}{|l|}{ Cr ratio } \\
\hline $\mathrm{NAA} / \mathrm{Cr}$ & -0.033 & 0.113 & -0.002 & $0.001^{*}$ & 0.006 & 0.737 \\
\hline $\mathrm{Glu} / \mathrm{Cr}$ & 0.050 & 0.096 & -0.003 & $0.003^{*}$ & 0.020 & 0.438 \\
\hline $\mathrm{Glx} / \mathrm{Cr}$ & 0.142 & $0.008 *$ & -0.003 & 0.092 & 0.088 & 0.055 \\
\hline Ins $/ \mathrm{Cr}$ & 0.008 & 0.664 & 0 & 0.994 & 0.003 & 0.852 \\
\hline \multicolumn{7}{|l|}{ Ins ratio } \\
\hline NAA/Ins & -0.049 & 0.146 & -0.002 & $0.011^{*}$ & 0.003 & 0.917 \\
\hline $\mathrm{Glx} / \mathrm{Ins}$ & 0.139 & $0.035^{*}$ & -0.003 & 0.115 & 0.090 & 0.111 \\
\hline
\end{tabular}

B: partial regression coefficient, $p$ : $\mathrm{p}$-value, ${ }^{*}: p<0.05$

系の一部であり, 痛みの認知や, 感情的プロセ スに関与する 2,19$) 。$ 代謝物質として，NAA（N アセチルアスパラギン酸), Glx (グルタミン+ グルタミン酸) を測定した。NAAは神経細胞 の密度を反映し9)，Glu（グルタミン酸）は興奮 性神経伝達物質として働く。本研究では, 慢性 腰痛患者においては, ACCにおける代謝物質 のうち，NAAが有意に低下し， Glx（グルタミ ン+グルタミン酸) / Cr (クレアチン ) 比が有 意に上昇した (Table 1)。この結果から, 慢性 腰痛では, 神経細胞の過興奮による神経ダメー ジ (excitotoxic neuronal damage $)^{7,22)}$ が, ACC の神経細胞の密度を減少させた可能性が考えら
れる。しかし，NAAは正常神経細胞内におい て恒常性を保つための重要な機能を担う分子で あり ${ }^{6)}, \mathrm{NAA}$ の変化が直接, 神経細胞数の変 化をとらえておらず，神経の機能異常を反映し ている可能性もある。代謝物質濃度の解釈につ いてはさらなる検討が課題の1つと言える。

\section{慢性腰痛患者の視床における 脳代謝物質の変化}

痛みによる中枢神経系の働きをとらえるにあ 
たり，脊髄視床路は痛みの伝導路の一つである ことから，視床での代謝物質を評価することは 有用である。矢吹ら ${ }^{26)}$ は, MRS 法を用いて, 慢性腰痛患者での視床, ACC, おょび前頭前 野で，NAA/Cr比と NAA/Cho（コリン）比を 評価した。また, 各症例の numeric rating scale（NRS 0〜10点の 11段階評価）との相関を 評価した。腰椎疾患により 2 12 カ月継続する 左側の腰痛，または下肢痛を有する 6 例と，対 照群の6例を設定した。慢性腰痛では, 疼痛領 域の対側の視床において $\mathrm{NAA} / \mathrm{Cr}$ 比の有意な 減少が梕められた（疼痛群：1.292 \pm 0.062 , 対 照群 : $1.536 \pm 0.172, p=0.025)$ 。また, NRS, は疼痛の対側の視床で, $\mathrm{NAA} / \mathrm{Cr}$ 比と負の相 関が認められた。神経障害性疼痛に抢いて，視 床での NAA 濃度の低下が報告されており ${ }^{18)}$, 本研究の結果からも, 視床におけるNAAの測 定は，痛みの客観的な評価と診断につながる可 能性がある。

\section{慢性腰痛患者への機械的疼痛刺激での 脳賦活部位の変化}

近年，機能的 MRI（fMRI）を用いた脳の評価 は，非侵襲的に痛みを評価する方法として多く の研究に用いられている (Fig.1)。小林ら ${ }^{14)}$ は, 非特異的慢性腰痛患者 6 人と健常人 8 人を対象 に, 腰部に圧迫刺激を与え, fMRIにより脳の 賦活部位を評価した。慢性腰痛は, visual analog scale (VAS 0 10点の 11段階評価) で3 以上の腰痛が 3 力月以上持続し, 神経学的所見 と腰椎MRI所見で異常が認められないものと 定義した。L4/5高位で, 正中から $5 \mathrm{~cm}$ 左側に, 空気を満たした $25 \mathrm{ml}$ シリンジを用いて圧迫す

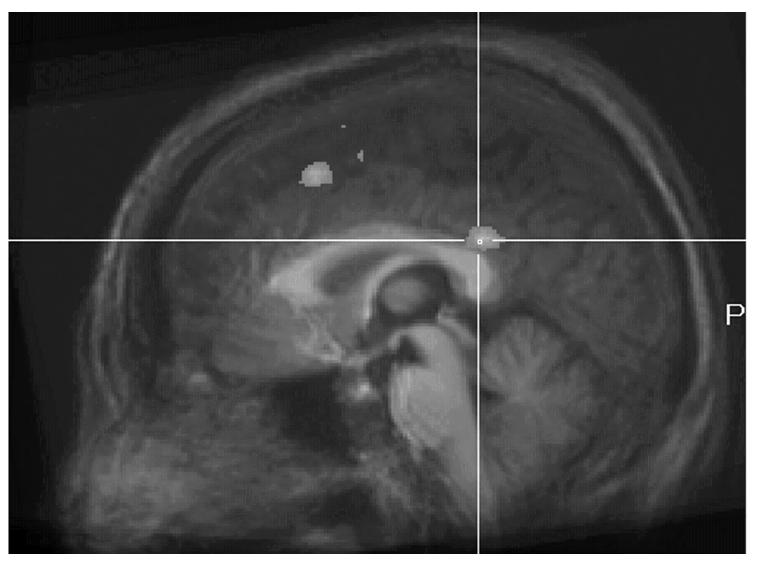

Fig.1 One example of result obtained by fMRI.

It showed that posterior cingulate cortex of chronic low back pain patients was activated by pain stimulation.

る疼痛刺激を課題 (タスク) とした。圧迫の程 度は, fMRI測定前に被験者ごとに, 痛みが VAS 3 とVAS 5 になる圧迫刺激を設定した。 fMRI測定時に同様の条件を再現した。タスク 誘発のパラダイムは, VAS 3 またはVAS 5 の夕 スクにおいて，30秒間の圧迫刺激と 30 秒間の 休䕀を 3 回繰り返した。腰痛群は健常群と比較 して, 弱い圧迫刺激に対して同じ程度の痛みが 誘発された。脳賦活部位は, 右半球の前頭前野, 島皮質, 後带状回, 補足運動野, および運動前 野に認められたが, 体性感覚野には認められな かった。腰痛患者は健常者と比較して, 特に右 島皮質, 補足運動野, および後帯状回で賦活化 が増加した。島皮質, 前頭前野, 補足運動野, 運動前野, 視床, 帯状回は pain matrix であり ${ }^{19}$, 特に帯状回は痛みの感情的側面や認知に関与す る 23)。腰痛患者では健常者と比較して同じ程度 の痛みでも, 痛みをより不快に感じていること が示唆された。治療に難渋する慢性腰痛患者を 扱う際には，脳の機能的変化が背景に存在する 可能性を考慮する必要がある。 


\section{慢性腰痛患者への機械的疼痛刺激での 脳賦活部位の変化に対する 精神医学的問題の関与}

慢性腰痛は, 精神医学的問題と深く関与して いる ${ }^{17,20)}$ 。金子ら ${ }^{12)}$ は, 非特異的慢性腰痛患者 を対象として精神医学的問題の有無による脳賦 活の相違について検討した。慢性腰痛は, NRS 1 以上の腰痛が, 3 力月以上継続すると定義さ れ, 慢性腰痛患者 21 名を対象とした。対象者 は整形外科疾患における精神医学的問題を見つ けるための簡易問診票 (BS-POP) 患者用27)を 用いて, 精神医学的問題あり群 (高得点群 : 17 点以上) 10 人と, 問題なし群 (非高得点群 : 17 未満） 11 人の 2 群に分類した。前述の研究と同 様の腰部圧迫タスクとして, fMRIを実施した。 実験パラダイムは，(1) 30 秒間の NRS 3 の圧迫 刺激を 3 回, (2) 30 秒間の NRS 5 の刺激を 3 回, (3) NRSが 3-3-5-5-3-5の順に行う 3パターン を設定した。精神医学的問題を有する群では, 問題のない群と比較して, 平常時の腰痛の NRS が有意に高く, 包括的健康関連 QOL (SF-36) は有意に低かった。(3)のパラダイムにおいて, 精神医学的問題を有する群では, 圧迫刺激によ り, 右の角回, 中側頭回, 縁上回, 三角部, 体 性感鸴野, 補足運動野, 両側の背外側前頭前野, 運動前野, 前頭葉眼球運動野, 前部前頭前野, 後帯状回, 左側の尾状核, および弁蓋部に有意 な賦活化が認められた。2群間の賦活化信号の 差を解析すると, 精神医学的問題を有する群で 側坐核の賦活化が減弱し, 側坐核の機能が低下

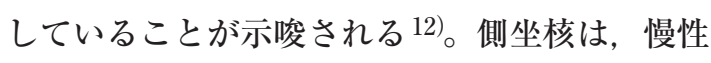
腰痛群と健常群の間に, 疼痛刺激の消失時の賦 活化の差が報告されている4)。側坐核の脳活性 より, 慢性腰痛患者における精神医学的問題の
背景を予測できる可能性がある。

\section{前帯状回と側坐核： 痛みと精神医学的問題の関与}

慢性腰痛に関与する帯状回や側坐核に着目し て過去の研究をいくつか紹介する。まず, 慢性 腰痛患者におけるMRSでの脳代謝物質変化は, ACC，島前部，および視床で報告されている10)。 また, 慢性腰痛が精神医学的問題と関係するこ とはすでに言及したが, うつ病でACCにおい て Glxが減少することがわかっている3)。さら に，MRSによる標的代謝物質の一つであるミ オイノシトール (Ins) は, グリア細胞の減少や 代謝の変化を表すと言われているが21), うつ病 でACCのInsの減少が報告されている8)。心理 社会的背景の影響度が強い脊髄損傷後の神経障 害性疼痛患者において, Insが高く, Glx/Ins が低いことが報告された ${ }^{24)}$ 。以上の事実から， 慢性疼痛と精神医学的問題の関係には, ACC での神経細胞での代謝異常が強く関与すること が示唆される。

側坐核は, 中脳辺縁系の一部であり, 腹側被 蓋野から側坐核や腹側淡蒼球へ軸索を伸ばす ドーパミン経路を形成している。痛み刺激は, 腹側被蓋野の神経に活動電位の群発射を引き起 こし，これにより腹側被蓋野から大量にphasic dopamineが放出される。このdopamineによ り側坐核や腹側淡蒼球で $\mu$ オピオイドが産生 され，痛みが抑制される25)。慢性のストレスに より, phasic dopamineの放出が抑えられ16), これにより痛みの増強が起こると考えられる。 また，神経ぺプチドの一つであるコルチコトロ ピン放出因子によって側坐核では $\mu$ オピオイ 
ドが放出されるが，強いストレスにさらされる と, コルチコトロピン放出因子によって起こる 側坐核での $\mu$ オピオイド放出が抑制される15)。 ACC と側坐核は, 痛みと精神医学的影響に よって大きく影響を受け，これらの病態の解明 に重要な脳領域であり, 今後のさらなる研究に より慢性腰痛の診断や治療に繋がりうることが 期待できる。

\section{おわりに}

脳イメージング研究では, 様々な脳機能や疾 患との関連が明らかになりつつある。しかしな がら，限界の一つとして，因果関係の順序が挙 げられる。今まで報告されている脳イメージン グ研究は横断研究が多く, とらえられた脳変化 が慢性痛によって起こるのか, 脳の変化によっ て慢性痛が起こっているのかが証明できない。 これを証明するには縦断研究が必要となる。覀 急性期の腰痛患者を対象とし, 安静時 fMRIを 施行した研究では，1年後に腰痛が慢性化した 群と治癒した群に分け, 再度 fMRIを施行する という手法を用いることで，覀急性期の皮質線 条体経路の機能的結合が因果的に腰痛の慢性化 に関与すると報告されている5)。脳イメージン グ研究を行う上で事象の因果関係を示すために 参考となる研究デザインと言える。

慢性腰痛では, ACCと, 視床に脳代謝物質 の変化が認められ, 腰部への疼痛誘発刺激によ る脳賦活部位は健常人と異なる変化が認められ る。さらに精神医学的問題の背景が存在する場 合には，側坐核での脳賦活が低下することが示 された。今後, これらの脳イメージング法を用 いた更なる病態の解明，慢性疼痛の診断および
治療効果判定への応用が期待される。

\section{文 献}

1) Andersson, G.B., Epidemiological features of chronic low-back pain, Lancet, 354 (1999) 581-585.

2) Apkarian, A.V., Bushnell, M.C., Treede, R.D., Zubieta, J.K., Human brain mechanisms of pain perception and regulation in health and disease, Eur. J. Pain, 9 (2005) 463-484.

3) Auer, D.P., Pütz, B., Kraft, E., Lipinski, B., Schill, J., Holsboer, F., Reduced glutamate in the anterior cingulate cortex in depression: an in vivo proton magnetic resonance spectroscopy study, Biol. Psychiatry, 47 (2000) 305-313.

4) Baliki, M.N., Geha, P.Y., Fields, H.L., Apkarian, A.V., Predicting value of pain and analgesia: nucleus accumbens response to noxious stimuli changes in the presence of chronic pain. supplemental information, Neuron, 66 (2010) 149160.

5) Baliki, M.N., Petre, B., Torbey, S., Herrmann, K.M., Huang, L., Schnitzer, T.J., Fields, H.L., Apkarian, A.V., Corticostriatal functional connectivity predicts transition to chronic back pain, Nat. Neurosci., 15 (2012) 1117-1119.

6) Baslow, M.H., N-acetylaspartate in the vertebrate brain: Metabolism and function, Neurochem. Res., 28 (2003) 941-953.

7) Bleich, S., Römer, K., Wiltfang, J., Kornhuber, J., Glutamate and the glutamate receptor system: a target for drug action, Int. J. Geriatr. Psychiatry, 18 (2003) S33-40.

8) Coupland, N.J., Ogilvie, C.J., Hegadoren, K.M., Seres, P., Hanstock, C.C., Allen, P.S., Decreased prefrontal myo-inositol in major depressive disorder, Biol. Psychiatry, 57 (2005) 1526-1534.

9) Govindaraju, V., Young, K., Maudsley, A.A., Proton NMR chemical shifts and coupling constants for brain metabolites, NMR Biomed., 13 (2000) 129-153.

10) Gussew, A., Rzanny, R., Güllmar, D., Scholle, H.C., Reichenbach, J.R., 1H-MR spectroscopic detection of metabolic changes in pain processing brain regions in the presence of non-specific chronic low back pain, Neuroimage, 54 (2011) 1315-1323.

11) Jensen, M.C., Brant-Zawadzki, M.N., Obuchowski, N., Modic, M.T., Malkasian, D., Ross, J.S., Magnetic resonance imaging of the 
lumbar spine in people without back pain, N. Engl. J. Med., 331 (1994) 69-73.

12) Kaneko, H., Zhang, S., Sekiguchi, M., Nikaido, T., Makita, K., Kurata, J., Konno, S., Dysfunction of Nucleus Accumbens Is Associated with Psychiatric Problems in Patients with Chronic Low Back Pain -A Functional Magnetic Resonance Imaging Study, Spine, 41 (2016) 111.

13) Kjaer, P., Leboeuf-Yde, C., Korsholm, L., Sorensen, J.S., Bendix, T., Magnetic resonance imaging and low back pain in adults: a diagnostic imaging study of 40-year-old men and women, Spine, 30 (2005) 1173-1180.

14) Kobayashi, Y., Kurata, J., Sekiguchi, M., Kokubun, M., Akaishizawa, T., Chiba, Y., Konno, S., Kikuchi, S., Augmented cerebral activation by lumbar mechanical stimulus in chronic low back pain patients: an FMRI study, Spine, 34 (2009) 2431-2436.

15) Lemos, J.C., Wanat, M.J., Smith, J.S., Reyes, B.A.S., Hollon, N.G., Van, Bockstaele, E.J., Chavkin, C., Phillips, P.E.M., Severe stress switches CRF action in the nucleus accumbens from appetitive to aversive, Nature, 490 (2012) 402-406.

16) Mangiavacchi, S., Masi, F., Scheggi, S., Leggio, B., De, Montis, M.G., Gambarana, C., Long-term behavioral and neurochemical effects of chronic stress exposure in rats, J. Neurochem., 79 (2001) 1113-1121.

17) Nicholas, M.K., Linton, S.J., Watson, P.J., Main, C.J., "Decade of the Flags" Working Group. Early identification and management of psychological risk factors ("yellow flags") in patients with low back pain: a reappraisal, Phys. Ther., 91 (2011) 737-753.

18) Pattany, P.M., Yezierski, R.P., WiderströmNoga, E.G., Bowen, B.C., Martinez-Arizala, A., Garcia, B.R., Quencer, R.M., Proton magnetic resonance spectroscopy of the thalamus in patients with chronic neuropathic pain after spinal cord injury, AJNR. Am. J. Neuroradiol., 23 (2002) 901-905.
19) Peyron, R., Laurent, B., García-Larrea, L., Functional imaging of brain responses to pain. A review and meta-analysis (2000), Neurophysiol. Clin., 30 (2000) 263-288.

20) Pincus, T., Burton, A.K., Vogel, S., Field, A.P., A systematic review of psychological factors as predictors of chronicity/disability in prospective cohorts of low back pain, Spine, 27 (2002) E109-20.

21) Pouwels, P.J., Frahm, J., Regional metabolite concentrations in human brain as determined by quantitative localized proton MRS, Magn. Reson. Med., 39 (1998) 53-60.

22) Rothman, S.M., Thurston, J.H., Hauhart, R.E., Delayed neurotoxicity of excitatory amino acids in vitro, Neuroscience, 22 (1987) 471-480.

23) Vogt, B.A., Pain and emotion interactions in subregions of the cingulate gyrus, Nat. Rev. Neurosci., 6 (2005) 533-544.

24) Widerström-Noga, E., Pattany, P.M., CruzAlmeida, Y., Felix, E.R., Perez, S., Cardenas, D.D., Martinez-Arizala, A., Metabolite concentrations in the anterior cingulate cortex predict high neuropathic pain impact after spinal cord injury, Pain, 154 (2013) 204-212.

25) Wood, P.B., Mesolimbic dopaminergic mechanisms and pain control, Pain, 120 (2006) 230234.

26) Yabuki, S., Konno, S., Kikuchi, S., Assessment of pain due to lumbar spine diseases using MR spectroscopy: a preliminary report, J. Orthop. Sci., 18 (2013) 363-368.

27) Yoshida, K., Sekiguchi, M., Otani, K., Mashiko, H., Shiota, H., Wakita, T., Niwa, S., Kikuchi, S., Konno, S., A validation study of the Brief Scale for Psychiatric problems in Orthopaedic Patients (BS-POP) for patients with chronic low back pain (verification of reliability, validity, and reproducibility), J. Orthop. Sci., 16 (2011) 7-13.

Address for correspondence: Takuya Kameda

Department of Orthopaedic Surgery,

School of Medicine Fukushima Medical University

1 Hikariga-oka, Fukushima 960-1295, Japan 